\title{
NORMATIVE APPROACH TO THE INTERPLAY BETWEEN THE CCC AND THE CJEU/ECTHR: JUDICIAL DIALOGUE OR A DICTATE?
}

\author{
David SEHNÁLEK ${ }^{1}$
}

The article aims to identify the rules governing the mutual relationships among the European Court of Human Rights, the Court of Justice, the constitutional courts of EU's Member States, and the EFTA Court. Its second goal is to determine to what extent their decisions and interpretive conclusions mutually bind these courts. The third goal is to present the approach taken by the Czech Constitutional Court towards the European Court of Human Rights and Court of Justice, and their decisions, on the one hand, and that of the Court of Justice to rulings made by the European Court of Human Rights and the EFTA Court, on the other hand. To find an answer to these questions, the article first analysis the normative settings and the links among individual legal systems and also among these courts. The second part of the article focuses on the case-law of these courts and thus on the reality of their "mutual" decision-making. The author concludes that there is a significant difference between the decisions of the Court of Justice and the European Court of Human Rights. While the former has the power to determine the binding and, therefore correct interpretation of EU law, the latter does not have comparable competence when it comes to the European Convention. Therefore, European Court of Human Rights decisions are only de facto binding. However, in the case law of the Constitutional Court, the exact opposite is the reality. The European Court of Human Rights judgments are unquestioningly respected and followed, while the approach to the Court of Justice's decisions oscillates between two extremes. Some of its decisions are fully reflected, while others are silently ignored. Similarly, the Court of Justice works differently with the European Court of Human Rights decisions and the EFTA Court. The Czech Constitutional Court and the Court of Justice also have in common that they treat decisions of the European Court of Human Rights (Czech Constitutional Court) and the EFTA Court (Court of Justice) basically like their own.

European Court of Human Rights

the Court of Justice

the Czech Constitutional Courts

EFTA Court

Precedent

1 | Associate Professor, Department of International and European Law, Faculty of Law, Masaryk University, Brno, the Czech Republic, david.sehnalek@law.muni.cz.

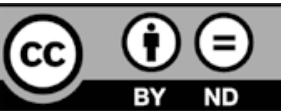




\author{
Principle of Homogeneity \\ the Correct Interpretation \\ the Binding Effects of Interpretation of Judicial Decisions \\ Protocol No. 16 to the European Convention
}

\title{
Introduction
}

The European legal space is specific in that it houses several supreme courts which overlap in their jurisdiction. The mutual relationships among these courts are not satisfactorily, clearly, and convincingly established, as each of them belongs to a different legal order and system. They are part of no clear hierarchy that would make it possible to resolve or avoid potential conflicts among these courts. This circle of courts includes 1) the European Court of Human Rights (ECtHR), 2) the Court of Justice of the European Union (CJEU), 3) the constitutional courts of European Union (EU) Member States, and 4) the European Free Trade Association (EFTA) Court.

The present article aims, first, to identify the normative rules governing the mutual relationships among these courts. Second, it attempts to determine to what extent, and whether at all, these courts are mutually bound by their decisions and interpretive conclusions. The third objective is to present the approach taken by the Czech Constitutional Court (CCC) towards the ECtHR and CJEU, and their decisions, on the one hand; and that of the CJEU to rulings made by the ECtHR and the EFTA Court, on the other hand. ${ }^{2}$ The article, thus, focuses on the views of courts that might be perceived as 'threatened' by an external interpretive authority of higher category. While the perspectives of the ECtHR and the EFTA Court would naturally be relevant, this would go beyond the reasonable scope of this study.

The approach we adopt is both normative and factual, based on the actual decisions of these courts.

Lawyers naturally assume that there must be some kind of hierarchy in the judiciary. It is always crucial for a lawyer to determine who will have the last word in a matter they are engaged in. From this perspective, the European space represents an environment characterised by uncertainty. The courts mentioned above are well aware of this issue. Therefore, they tend to try and avoid mutual contradictions in their decisions. The question this study seeks to answer is whether a final interpretive authority can be established de iureor at least de facto in the European space.

The search for this answer is organised in two stages. The first part of the article uses a normative approach to lay out some general systemic questions. The focus is primarily on the links among individual legal systems (legal orders, i.e. laws of individual jurisdictions) and also among the supreme courts. The reason is simple: the question of how one court influences another is often reduced to the nature of the ensuing decision-whether it is binding, and if so, in what way it serves as a precedent. However, is the fact that that these considerations are only relevant in the framework of a single legal system tends to be neglected. The situation is somewhat more complicated with regard to the ECtHR,

2 | Whereas the first objective focuses on the normative approach, the third explores real practice of the courts. 
the CCC, the EFTA Court, and the CJEU. The decisions rendered by these courts constitute parts of various legal systems, which may-but need not-define what effects these decisions have and whether or not they are binding. This has often been disregarded in the literature.

The second part of the present article focuses on the reality of 'mutual' decisionmaking by individual courts. The simplistic approach used in the literature can owe to the fact that individual courts neglect their mutual systemic links, do not follow up on these links, and treat judgements coming from other courts equivalently. What is also important in this regard is to what extent-and whether at all-they actually take each other's interpretations into consideration.

This article deals primarily with the protection of human rights and freedoms. From this perspective, the EFTA Court's involvement might appear unsystematic at first sight. Nonetheless, there are two reasons for not leaving this court out of our analysis. First, the way this court is asked to interpret the EEA Agreement is very specific, and this, in turn, makes it possible to compare its modus operandi with cases not involving such settings, as is true of the European Convention. Second, this is because we can objectively compare decision-making by the CJEU with that of the ECtHR (sic). The picture would be incomplete without such a comparison.

However, this study does not examine what can serve as a precedent, i.e. whether decisions rendered by the ECtHR, the CCC, the EFTA Court, and the CJEU are binding ergaomnes; which parts of their decisions have binding effects; etc. While these questions may certainly be interesting and relevant from the legal point of view, their examination would go beyond the scope of this study. Thus, the sole decisive aspect is whether a court included in our analysis is bound to follow the interpretation of a legal norm provided by another court.

\section{Normative approach to the relationship among legal systems, binding effects of judicial decisions, and interpretation.}

As a starting point, we define the basic concepts and establish the general background. The study focuses on courts and their decisions, with an emphasis on the binding effect of these decisions and the interpretations they provide. A systemic approach to this problem is often neglected in case law and literature. Judicial decisions are treated as a general category, regardless of which courts issue them. However, such an approach is problematic and simplistic in terms of the theory of law. This situation can be classified as follows.

1. The ECtHR and the EFTA Court interpret and apply sources of public international law.

2. Constitutional courts interpret and apply national laws and, in some cases concerning the protection of human rights, public international law, and potentially EU law. EU law comes into play, especially if the Constitutional Court's review touches on a rule that partially or fully originates from EU law.

3. The CJEU primarily interprets and applies EU law and public international law. 
As a result, the nature, effects, and binding nature of judicial decisions must be addressed in view of the mutual links among the individual legal systems. Analogously, we must deal with the mutual links among these courts as institutions.

\subsection{On the interpretation of public international law: the perspective of a national (Czech) court}

The interpretation of public international law is governed by the rules of this law. ${ }^{3}$ In contrast, its national effects (i.e. the conditions of its application) are mediated by national laws. In the Czech Republic, they are set out in Art. 10 of the Constitution, ${ }^{4}$ which considers some international treaties directly applicable in Czech law. ${ }^{5}$ In practice, international treaties covered by this provision become part of the law ${ }^{6}$ which is to be interpreted and applied by Czech courts. However, the interpretation of these treaties is autonomous. International treaties for the protection of human rights and freedoms form a special category sui generis in the Czech legal system. They are considered a part of the Czech constitutional order and, therefore, serve as a benchmark for assessing the constitutionality of ordinary laws (statutes). ${ }^{7}$ However, this changes nothing about the fact that they are a source of public international law. The mechanism of their (autonomous) interpretation is, therefore, not affected.

The Czech Constitution governs the relationship between national and international laws, but deals only with the national effects of international treaties. It remains silent in this regard about the decisions issued by international organisations and their bodies. The nature and effects of such decisions can be established and derived from the international treaty which created the given international organisation, and are mediated again through national law. Czech (national) courts are bound by the given international treaty and the way it has been interpreted by an authority of the given international organisation.

Practically speaking, this means, in general, that Czech (national) law first makes it possible to apply an international treaty in the Czech Republic. At the same time, its interpretation is provided in the manner envisaged by that treaty, provided that it comprises such rules. A specific international institution may be involved in the interpretation process. The Czech Republic and its courts must subsequently respect the interpretation provided by such an institution, as they are bound by the relevant treaty. If such rules are absent and no international institution is appointed to ensure correct interpretation, the courts of the contracting states interpret the given international treaty themselves.

3| These rules are codified for international treaties in the Vienna Convention on the Law of Treaties.

4| Art. 10 of the Czech Constitution states: 'Promulgated treaties, to the ratification of which Parliament has given its consent and by which the Czech Republic is bound, form a part of the legal order; if a treaty provides something other than that which a statute provides, the treaty shall apply.'

5 | Only some international treaties are directly applicable in the Czech legal order, as only privileged treaties (presidential/parliamentary) are included in the incorporation clause of the Art 10 of the Czech Constitution.

6 | It is sometimes incorrectly postulated that they become a part of Czech law.

7 | Decision of the Constitutional Court Pl. ÚS 36/01 of 25 June 2002. 
A mechanism involving an international institution partially applies in the case of the ECtHR and the European Convention. The latter assumes that the Czech Republic, as a contracting state of this international treaty, will follow ECtHR judgements in proceedings to which it was a party. ${ }^{8}$ However, the European Convention does not require the Member States and their courts to respect the ECtHR's judgements in general, i.e. in all cases, including the proceedings in which they were not involved. Therefore, it cannot be concluded that the European Convention directly establishes the ECtHR's general power to provide binding and correct interpretation of its text, which would generally have to be followed by courts of the contracting states. There is no explicit normative basis for such a statement. Thus, the Member States and their courts have some room for the autonomous interpretation of this international treaty. Furthermore, the European Convention contains no rule according to which the ECtHR judgements would serve as a source of law or be generally directly applicable in the contracting states. ${ }^{9}$

A relative novelty is Protocol No. 16 to the European Convention, which introduces a mechanism of advisory opinions on questions of principle relating to the interpretation or application of the rights and freedoms defined in the Convention or the protocols to the Convention. ${ }^{10}$ These opinions will not be binding; therefore, Protocol No. 16 does not make the ECtHR a supreme interpretive authority. This, in no way, diminishes the actual significance of these advisory reports once the protocol enters into force. It is likely that the ECtHR's informal authority will persuade national courts to follow such opinions voluntarily in practice.

\subsection{On the interpretation of EU law: the perspective of a national (Czech) court}

The situation is different in the case of EU law. EU law is autonomous in relation to both national law and public international law. Unlike public international law, it has a supranational nature and determines the effects it will have on the Member States (i.e. it will be applied directly and with priority over any national law and, thus, also constitutional law). It also determines the rules of its own interpretation. Although the primary law is composed of international treaties, the Vienna Convention on the Law of Treaties is not used for its interpretation. From this point of view, national constitutional provisions, such as Art. 10 of the Constitution in the Czech Republic, as mentioned above, are irrelevant. Consequently, the effects of acts taken by the EU institutions and, thus, of the decisions of the CJEU, are specified by EU law, and not by national law.

The practical consequence of the above is that the space for interpretation of EU law by national courts of the Member States is substantially restricted. The CJEU provides correct and binding interpretation. This power of the CJEU is derived from Art. 19 TEU, according to which it "[...] shall ensure that in the interpretation and application of the Treaties the law is observed.' This provision is construed as giving this body an exclusive position in interpreting EU law. ${ }^{11}$ The interpretation of EU law provided by the CJEU in its decisions is,

8 | See Art. 46 of the European Convention.

9 | However, the prevailing opinion in Czech legal doctrine is that the Czech Repulic is de facto obliged to comply even with decisions rendered in proceedings concerning other states. The truth is that such an obligation might be set by the domestic law.

10 | See Art. 1 of Protocol No. 16.

11 | TÝČ, 2017, p. 108. 
therefore, binding to EU Member States and their judiciary. ${ }^{12}$ Judgements of the CJEU are deemed to be (quasi-)precedential. While they do not serve as a source of law as they are not binding ergaomnes, in view of the nature of EU law, they are directly and, thus, without any mediation binding on national courts as to the way they interpret EU law.

It could be argued that the previous paragraph only reflects the stance of the CJEU. Some constitutional courts accept the principles of application of EU law formulated by the CJEU only partially or subject to certain conditions. The CCC belongs to these courts..$^{13}$ The perspective of the national constitutional courts is understandable. They accentuate the derived nature of the EU and its powers. These could only be derived from national laws and within their limits, which are primarily comprised of the respective national constitutions. I also accept this position, but only to a certain extent. I believe that there is a substantial difference between the founding Member States of the EU and the accession countries. The founders were presented with a fait accompli by the CJEU. Acceding countries, in contrast, knew the circumstances fully and decided to accept the acquis communautaire to its full extent, thus including the way the CJEU had defined the characteristics of EU law. Therefore, it is not acceptable for their judiciary to influence and restrict, through its case law, the lawmaker's decision to make the country a part of the $\mathrm{EU}$, as this international organisation operates according to case law of the CJEU.

\section{| 1.3. On the interpretation of public international law: the perspective of a EU court}

\subsubsection{Relationship between the EU and international law, and interpretation of interna-} tional law in general; interpretation of the European Convention

Everything that has already been said regarding the relationship between national and international laws applies per analogiam to the relationship between EU law and international law, and to the interpretation of the latter. EU law 'takes the place' of national law and lays down the conditions under which sources of public international law may have effects in EU law and in the law of the Member States. The specific solution is based on case law of the CJEU, since this question is not addressed in primary law, unlike in national constitutions. In principle, the solution devised by the CJEU is very similar to the mechanism in Art. 10 of the Czech Constitution. The difference is that the Czech Constitution does not make international treaties a part of Czech law. ${ }^{14}$ In contrast, according to the CJEU, international treaties concluded by the Union have this status and form a part of EU law. ${ }^{15}$

12 | The Court of Justice has had this competence from the very beginning of its existence. Art. 31 of the Treaty establishing the European Coal and Steel Community, Art. 136 of the Treaty establishing the European Atomic Energy Community, and Art. 164 of the Treaty establishing the European Economic Community, as well as Art. I-29 of the Treaty establishing the Constitution for Europe, and the current wording of Art. 19 of the Treaty on the European Union have materially identical wording and have not undergone any change over time that could affect the concept and role of the Court of Justice of the European Union in interpretation of EU law.

13 | For a comprehensive analysis of the case law of the CCC, see Hamulák, 2016, pp. 65-77.

14 | Art. 10 of the Czech Constitution is misleading as it uses formulation that treaties ,... form a part of the legal order'. This has to be understood that they are part of the directly applicable law in the country. On the contrary, international treaties do not become part of the Czech legal order utsel. Thus, it makes no sense to speak about their legal force in the Czech legal order in relation to its other sources.

15 | Thus, in case of EU law, international treaties may be used as a foundation for derogation of secondary law as they do have higher legal force than secondary law. 
This study focuses on the issue of the binding effects of interpretation of judicial decisions in the area of human rights and freedoms. Therefore, the European Convention and its position in EU law are primarily relevant. The ECtHR rulings' influence on the CJEU is also significant in this regard. It is a fact that the EU is still not a party to the European Convention. ${ }^{16}$ While Art. 6(2) TEU anticipates that the Union will accede to this treaty, this is yet to materialise. It should be noted that the Council of Europe has already eliminated obstacles to the EU'S accession ${ }^{17}$ by adopting Protocol No. 14 to the Convention for the Protection of Fundamental Rights and Freedoms. ${ }^{18}$ However, problems persist on the part of the Union. In Opinion 2/13, the CJEU found the draft mutual agreement incompatible with the founding treaties.$^{19}$ It should be recalled that this was not the first time this happened, although the legal grounds were different in the previous instance..$^{20}$

Thus, it holds that the EU and CJEU have no duty under international public law to comply with the European Convention. The CJEU cannot be the addressee of the ECtHR decisions. ${ }^{21}$ Nevertheless, the European Convention still affects the decision-making of the CJEU. EU law itself demands this. The EU Treaty states that '[f]undamental rights, as guaranteed by the European Convention for the Protection of Human Rights and Fundamental Freedoms and as they result from the constitutional traditions common to the Member States, shall constitute general principles of the Union's law.'22

General principles are an unwritten source of EU law and are, thus, subject to interpretation by the CJEU according to the rules of interpretation inherent to EU law. However, this does not apply in absolute terms. The Charter of Fundamental Rights of the EU further provides that ' $[i] n$ so far as this Charter contains rights which correspond to rights guaranteed by the Convention for the Protection of Human Rights and Fundamental Freedoms, the meaning and scope of those rights shall be the same as those laid down by the said Convention. This provision shall not prevent Union law from providing more extensive

16 | Nevertheless, according to the Court of Justice, EU law must be interpreted in the light of the relevant rules of international law, since international law is part of the EU legal order and is binding on the EU institutions. See judgement of the Court of Justice of 16 October 2012 in Hungary v Slovakia, Case C-364/10, para. 44.

17 | On the relationship between the European Union and the Convention for the Protection of Human Rights and Fundamental Freedoms, see e.g. Kujer, 2011.

18 | See Art. 15 of Protocol No. 14. Protocol to the Convention for the Protection of Human Rights and Fundamental Freedoms, amending the control system of the Convention. Available at: https:// rm.coe.int/.

$19 \mid$ A detailed analysis of the reasons goes beyond the scope and focus of this article. See e.g. Forejtová, n.d.

20 | The reason lay especially in the lacking competence on the part of the European Community at that time and the impossibility to cure this shortcoming, even on the basis of Art. 352 of the Treaty on the Functioning of the European Union (at that time, Art. 308 TEC). See the opinion of the Court of Justice of 28 March 1996. Accession by the Community to the European Convention for the Protection of Human Rights and Fundamental Freedoms. Opinion 2/94.

21 | Responsibility is borne in this regard not by the EU, but rather the individual Member States. They cannot avoid this responsibility by claiming that a certain decision violating the European Convention was not adopted by them, but rather by an international organisation to which they have entrusted a part of their powers. This follows from the ECtHR case law, e.g. from the judgement of the ECtHR, sitting as a Grand Chamber, in the case of Bosphorus Hava Yolları Turizmve Ticaret Anonim Şirketi v Ireland of 30 June 2005, file No. 45036/98.

22 | Art. 6(3) of the Treaty on the EU. 
protection'. ${ }^{23}$ What is especially noteworthy is that this provision speaks exclusively about the Charter and its contents and, in contrast, does not explicitly mention the ECtHR, its decisions, and its interpretation activities.

The question is what rationale is behind the given provision. It is apparent that it lies in the need to ensure that interpretation by the CJEU of standards adopted from the European Convention does not yield different results. The same text can be interpreted differently if methods other than linguistic ones are also considered. A problem may be linked, especially with the rule of interpretation of international treaties, according to which such interpretation has to reflect the purpose of these treaties. ${ }^{24}$ The purpose of the EU and its law is primarily to achieve economic integration, while the purpose of the European Convention is to protect human rights. ${ }^{25}$ Therefore, the Court's interpretation can be specific, precisely in view of the mission it fulfils. In my opinion, the mentioned provision aims to address this problem, as it anticipates either conforming interpretation or a deviation that will ensure a higher level of protection. As a result, the CJEU should not adapt the interpretation of the European Convention unilaterally to the standard of EU law.

In the case of national law and national courts, I have noted cases where a national court was bound by a ruling rendered by the ECtHR and, thus, also by the way the European Convention had been interpreted by that court. Although the preceding paragraph could indicate the opposite, no similar conclusion can be made in relation to the CJEU. There is no normative basis for doing so. The respective positions of the two courts are parallel and independent; neither of them is superior to the other. Consequently, although the CJEU is required to make decisions according to the same norms as the ECtHR, it is not formally bound by interpretation which the latter considers correct.

The question is whether it would be possible to find support for the opposite argument in EU law. The logic could be, for example, that the EU and, thus, also the CJEU should not allow-through their actions-violation of external obligations under public international law. Member States of the EU are bound by the European Convention and, therefore, an organisation established by the Member States must comply with the standards laid down in this Convention, and cannot serve as a pretext for non-compliance. However, this purpose cannot be achieved in this case by reference to Art. 351(1) TFEU, which- from the viewpoint of the EU Member States- aims to ensure compliance with the principle of pacta sunt servanda. ${ }^{26}$ Third countries will in no way be affected by any potential differing interpretation provided by the CJEU.

The binding effect of the ECtHR case law also cannot be inferred from the Charter of Fundamental Rights of the EU. While the latter states that '[ $t$ ] he explanations drawn up as a way of providing guidance in the interpretation of this Charter shall be given due regard

23 | Art. 52(3) of the EU Charter.

24 | Art. 31(1) of the Vienna Convention on the Law of Treaties.

25 I Cf. the arguments presented in an analogous case concerning its relationship to the EEA Court in the opinion of the EU Court of Justice of 14 December 1991. Draft agreement between the Community, on the one hand, and the countries of the European Free Trade Association, on the other, relating to the creation of the European Economic Area. Opinion 1/91, paras. 49 and 50.

26 | Art. 351(1) of the Treaty on the Functioning of the EU holds that ' $[t]$ he rights and obligations arising from agreements concluded before 1 January 1958 or, for acceding States, before the date of their accession, between one or more Member States on the one hand, and one or more third countries on the other, shall not be affected by the provisions of the Treaties.' 
by the courts of the Union and of the Member States', ${ }^{27}$ and the explanations add that '[t] he reference to the ECHR covers both the Convention and the Protocols to it. The meaning and scope of the guaranteed rights are determined not only by the text of those instruments, but also by the case law of the European Court of Human Rights and by the Court of Justice of the European Union'28, these explanations are not legally binding. The phrasing used is also very cautious as it is stated that 'due regard' shall be given, ${ }^{29}$ and not that the courts 'are bound'. Finally, historical interpretation also contradicts such a concept, because no explicit mention of the binding effect of case law was included in the Charter, although it was considered as one of the options. ${ }^{30}$

1.3.2. Relationship between the EU and international law, and interpretation of international law in a specific case of the EEA Agreement and the EFTA Court

In contrast to the way human rights are protected in the Council of Europe, the relations between the EU and a part of the EFTA Member States ${ }^{31}$ are regulated in detail in the EEA Agreement. Given that the EU is involved in this international treaty ${ }^{32}$, it forms a source of EU law. It regulates economic issues and, therefore, has a 'sub-constitutional' character. However, the interpretation of this treaty is generally governed by the rules of public international law.

The difference compared to the European Convention lies in the fact that the EEA Agreement may be applied and interpreted directly by the CJEU. In the case of the European Convention, the CJEU applies and interprets the general principles of law whose contents are determined by the Convention.

Given that the EEA Agreement is a common international treaty, there is a potential problem with its interpretation, which-similar to a majority of international treaties-is not centralised and can differ on both sides of the Agreement.

What is specific for the Agreement is that a number of its provisions are identical to those of the TFEU. However, as the Agreement is an international treaty, the notions used therein may carry different meanings than the same terms as they are inherent to EU law. ${ }^{33}$

Both the EU and the member states of the EFTA were aware of these two risks and sought to address them. Regarding the possibility of varying interpretations of the same notions under the EEA Agreement and EU law, the solution is provided in the preamble of the Agreement, which states that in full deference to the independence of the courts, the objective of the Contracting Parties is to arrive at, and maintain, a uniform interpretation and application of this Agreement and those provisions of Community legislation

27 | Art. 52(3) of the Charter of Fundamental Rights of the EU.

28 | Explanations relating to the Charter of Fundamental Rights (2007/C 303/02). Available at: http://eur-lex.europa.eu.

29 | The German and English language versions are phrased similarly as the Czech version, i.e. as a recommendation.

30 | Lock, 2015, pp. 182-183.

31 | The co-operation based on the EEA Agreement does not apply to Switzerland.

32 | As one contracting party together with the Member States of the EU.

33 | See the judgement of the Court of Justice of 26 October 1982 in Hauptzollamt Mainz v C. A. Kupferberg $\&$ Cie KG a. A, Case 104/81, para. 30; or its judgement of 9 February 1982, Polydor Limited and RSO Records Inc. v Harlequ In: Records Shops Limited and Simons Records Limited, Case 270/80, para. 15. 
which are substantially reproduced in this Agreement and to arrive at an equal treatment of individuals and economic operators as regards the four freedoms and the conditions of competition.' Therefore, interpretation and application of the Agreement and of the law adopted on its basis are expected to be homogeneous. What is always important in this regard is the result. The reasoning of rulings rendered by the CJEU and the EFTA Court can differ, including the arguments used therein, provided that the resulting decisions are the same. ${ }^{34}$

The issue of interpreting the EEA Agreement is also addressed in Art. 6, which aims to ensure the homogeneity of its interpretation with EU law. Thus, this provision deals with the problem of lacking a central final interpretive authority. It is assumed that identical or similar rules contained in the Agreement will be interpreted in conformity with case law of the CJEU preceding the signature of the Agreement. ${ }^{35}$ Thus, the EFTA Court is solely required to consider case law adopted by the CJEU after the signature of the EEA Agreement ${ }^{36}$. However, there is no practical difference in the ways the EFTA Court applies case law adopted before and after the execution of the EEA Agreement. ${ }^{37}$ As a result, the interpretation of EU law provided by the CJEU affects and predetermines the interpretation of the EEA Agreement.

\subsubsection{Interpretation of the European Convention by the courts of the Member States in} the fields of EU law

It was already noted above that the standards contained in the European Convention constitute the general principles of EU law. Indirectly-via general legal principles-the rules comprised in the European Convention have, thus, become a part of EU law, and the same is true of conclusions reached by the ECtHR which have later been voluntarily adopted by the CJEU in its case law.

This statement has a serious impact on the work of the national judiciary. National courts can apply the European Convention directly on the basis of national constitutional rules. However, the same Convention can also be applied, or more accurately, reflected indirectly via EU law.

In the first case, the conditions based on which the European Convention is applied are laid down by national law (i.e. Czech law). In the second case, they are laid down by EU law.

Consequently, the former case (national rules) can leave some room for setting the conditions under which the ECtHR case law is reflected by national courts. The possibility of interpreting the European Convention might even be modified, restricted, or subjected to certain conditions by virtue of national acts. In the latter case (EU rules), national law has no such options available, as EU law clearly lays down the principles of application. Any failure to respect the ECtHR case law in the latter case can result in violation not only of the European Convention, but also of EU law.

34 | That is why reference is also made to 'creative homogeneity'. See Hlinková, 2016, p. 110.

35 | Cf. also the opinion of the Court of Justice of 14 December 1991. Opinion 1/91, para. 46, which confirms this approach.

36 | See Art. 3 of the Agreement between the EFTA States on the Establishment of a Surveillance Authority and a Court of Justice (Surveillance and Court Agreement).

37 | Hlinková, 2016, p. 109. 
I am not aware of any case in which the conditions of applying the European Convention would be differentiated in this way in the Czech Republic. Moreover, no problems arise in this regard. This is because of the highly accommodating approach taken by the CCC to decisions rendered by the ECtHR, which means de facto that the European Convention is applied directly and with priority over Czech law (or more accurately, together with it). The Convention is, thus, applied in the same way as EU law-as the country's own law, i.e. Czech law. The only problematic situation is, therefore, a case in which a decision made by the CJEU differs from that taken by the ECtHR. Although this is quite unlikely in practice, it cannot be excluded. In my opinion, the correct solution (from the viewpoint of EU law) would be for the CCC to prefer interpretation provided by the CJEU to interpretation used by the ECtHR. However, I am afraid that the CCC would be hesitant to adopt this solution unambiguously.

\subsection{Mutual positions of the ECtHR, the CJEU, the EFTA Court, and the constitutional courts}

The ECtHR, the CJEU, the EFTA Court, and the constitutional courts are independent bodies of the judiciary and, therefore, any hierarchy among these authorities is out of the question. These courts do not form part of a single judicial system. Summarising the above, we can state as follows:

I The ECtHR and CJEU are absolutely independent of each other in legal terms. They operate in parallel because they have the powers to address one and the same question, each from their own point of view. Interpretation comprised in a decision of one of these courts is in no way legally binding on the other court. However, they are still in a competitive position. A decision rendered by one court can have a direct influence on the other.

I Parallel positions are also characteristic of the CJEU and the EFTA Court. However, the quality of their relationship is different. When interpreting the EEA Agreement, the EFTA Court is largely subordinate to the CJEU and is bound by the interpretation provided by the latter. There is no competitive relationship between these courts.

National constitutional courts are subordinate to the CJEU in matters of interpretation. EU law must be interpreted in the way prescribed by the CJEU. National courts have some room for their own creative interpretation only and exclusively within the limits set by EU law and the CJEU.

I The relationship between the constitutional courts and the ECtHR is also unequal. Constitutional courts are required to follow the ECtHR's decisions in proceedings where the country in question is a party to the dispute. Interpretation provided by the ECtHR is also binding on them to this extent. In all other cases, there is no explicit normative basis for inferring any relationship of superiority or subordination. However, as the correctness of interpretive conclusions reached by constitutional courts can be tested before the ECtHR, there can be no competitive relationship between the courts. The ECtHR will have the final say. 


\section{Reality of relationships among individual supreme courts}

\subsection{Relationship between the CCC and the ECtHR in case law of the CCC}

Focusing on the objective of this study, this section will explore how Czech law and the CCC approach the ECtHR's decisions in practice. The Constitutional Court has commented on the issue of the binding effects of the European Convention and rulings of the ECtHR in several of its decisions. The rhetoric of its case law is consistent, and so is its decision-making.

The Constitutional Court has expressed itself quite unambiguously with regard to decisions of the ECtHR concerning the Czech Republic. It concluded as follows:

'Direct applicability of international treaties also includes the duty of Czech courts and other public authorities to take account of interpretation of these treaties by the competent international tribunals as bodies called on to comment authoritatively on the interpretation of international treaties. This naturally also applies to interpretation by the ECtHR, where the relevance of the ECtHR's decisions attains the level of constitutional law in Czech practice. Decisions of the ECtHR are binding in individual cases on the Czech Republic and its public authorities in the territory of this country, which also follows from Art. 46(1) of the Convention, which declares that the binding effect of the ECtHR's decisions in individual cases is a "res judicata" characteristic of these decisions'. ${ }^{38}$ It also stated that 'there can be no doubt that the contents of a binding ECtHR judgement in a case against the Czech Republic constitute an obligation following for the Czech Republic from international law. The Czech Republic is required to comply with such obligations not only under international law, but also with reference to Art.1(2) of the Constitution." ${ }^{39}$

However, in the CCC's concept, the binding effect of the ECtHR case law is not limited only to cases directly concerning the Czech Republic. On the contrary, according to the CCC, Czech courts are obliged to also take the ECtHR case law into account in cases involving another country, but relevant for interpretation of the European Convention in the Czech context. At the same time, I consider it legally problematic that this obligation applies all the more in a situation where such case law is invoked by a party to proceedings before a Czech common court'.40 Thus, the Constitutional Court mixes up the procedural and substantive aspects of the subject. In procedural terms, it is appropriate to deal properly with arguments put forth by a party to the proceedings. However, this argument is irrelevant in material terms. The facts of the case and the legal regulations that should be applied in the given case are primarily important.

The above indicates a very accommodating approach of the CCC to the ECtHR's case law. What is also quite apparent is the Court's frustration with the common courts' ignorance of this case law. Czech courts have the duty to promote fundamental human rights and freedoms, as the Constitutional Court plays only a subsidiary role in this regard. Therefore, they should know well the contents of human rights and freedoms.

$38 \mid$ Decision of the CCC Pl. Ús 26/11 of 28 February 2012.

39 | Decision of the CCC File No. II. ÚS 604/02 of 26 February 2004, repeated in CCC decision Pl. ÚS 26/11 of 28 February 2012.

40 | Decision of the CCC Pl. ÚS 26/11 of 28 February 2012. 
What is also clear is the CCC's effort to educate and motivate the common courts to work with the ECtHR case law. This can be demonstrated by the CCC's statement that 'the Constitutional Court perceives the unlawful nature of the decision in interpretation of the Responsibility of the State Act which did not conform to the constitutional order, also including the Convention (based on interpretation provided by the ECtHR). The case at hand illustrates the alarming fact that common courts do not know (or ignore) case law of the ECtHR, whereby they not only negate national remedies in cases of violation of the Convention, but even expose the Czech Republic to the risk of international responsibility for breach of obligations following from the Convention' ${ }^{41}$

It should be added that the CCC's decisions correspond to its rhetoric. Thus, the saying 'preach water, drink wine' certainly does not apply in this case. The rulings of the CCC concerning human rights clearly indicate its open approach towards the European Convention and the ECtHR decisions.

I believe in this regard that the 'principle of homogeneity' can be considered to have become a part of Czech constitutional law as a result of the CCC's decisions. The CCC interprets the same rights protected by the Charter and the Convention in the same way. The ECtHR case law is often and broadly reflected in the interpretation process. The way the Court works with these decisions is qualitatively comparable to the manner in which the CCC treats its own earlier decisions. At the same time, if there is a difference in the wording of a right enshrined in the Charter and the same right protected by the European Convention, this difference tends to be neglected (not highlighted) and the right is still interpreted homogeneously, according to the European Convention. ${ }^{42}$

However, the relationship between the CCC and the ECtHR is not completely idyllic. One way to avoid a conflict is to pretend that it does not exist. The CCC has openly adopted this strategy towards the CJEU. It avoids a direct conflict by refusing to interpret or even apply EU law. This practice is not so clear with regard to the European Convention and the ECtHR, but I believe that the CCC still uses this strategy actively, albeit not very often.

I am aware of only one decision where the CCC did not openly agree with the conclusions reached previously by the ECtHR. This was the decision in Smatana, ${ }^{43}$ where the CCC stated as follows: 'In spite of the Court's disagreement with the conclusions made by the European Court of Human Rights in the case of Smatana v. the Czech Republic ..., where the Constitutional Court was described as a remand court (using this logic, the ECtHR itself could be considered a remand court), it can be agreed that all governmental authorities have the duty to ensure a defendant is not remanded in custody longer than reasonable (Section 102). In addition, it follows from settled case law of the Constitutional Court that, as a rule, all remand cases are dealt with preferentially and even without a motion, because of the quality of the fundamental freedom concerned in such a case, i.e. personal freedom limited by the remand in custody. There is no reason to change this practice and the case at hand was therefore found urgent and the constitutional complaint heard preferentially'.

The significance of this case is somewhat relativised by the fact that there was no actual conflict here, as the constitutional complaint was eventually found unjustified. The case is marginal and says nothing about the CCC'S relationship with the European

41 | Decision of the CCC File No. II. ÚS 862/10 of 19 May 2010.

42 | This can be clearly demonstrated on decision I. ÚS 2617/15.

43 | Decision of the CCC File No. II. ÚS 2395/09 of 8 October 2009. 
Convention and the ECtHR. In general, it holds in my opinion that the CCC does not show any tendencies towards analysing and discussing the ECtHR case law in greater detail, and adheres to it in the vast majority of cases.

\section{| 2.2. Relationship between the CCC and the CJEU in CCC case law}

This section of the article is very brief. Indeed, the CCC is yet to give its 'European legal doctrine' unambiguous contents. The approach to EU law and the protection of human rights ensured by EU law is, thus, characterised in the CCC's case law as follows:

1. EU law as a whole is not a reference system in the review of the constitutionality of national law. 44

2. Where EU law is taken into account, it is only done indirectly through its radiation into national law. ${ }^{45}$

The CCC's case law, specifically concerning the EU Charter, is more colourful, especially in the case of decisions made by individual chambers. In practice, the EU Charter is considered to be a part of the reference framework for review and a criterion for review, and Czech law emphasises the need to also approach interpretation of the law from the viewpoint of the EU Charter. ${ }^{46}$ A greater or lesser willingness to take the EU Charter, as a highly specific source of EU law, into consideration can be found in the individual decisions of the CCC. In some cases it is not taken into the account at all. ${ }^{47}$

The differences in the CCC's approach to the European Convention and the EU Charter are understandable. The Convention has an exceptional position among the sources of law used by the CCC, and the EU Charter cannot match it in this regard. Its scope is limited based on the rule 'if EU law applies, the Charter applies', which the CCC has embraced. ${ }^{48}$

The above includes the CCC's approach to EU law in general. The second question is the interpretation of EU law by the CCC and, in particular, the way the CCC approaches the possibility of initiating a preliminary ruling procedure. A detailed analysis of this issue would provide sufficient material for a separate article. Therefore, I shall merely summarise the basic principles followed by the CCC. First, by openly declaring that EU law is not a part of the constitutional reference framework, the CCC makes it clear that it cannot see any need to interpret it. In its concept, this is the task of the common courts. ${ }^{49}$ If the CCC nevertheless provides such interpretation, this is not to authoritatively determine the contents of the law, but to make it possible to assess the case in terms of Czech constitutional law..$^{50}$ Second, the CCC does not consider itself a court or tribunal within the meaning of Art. 267 TFEU. While it does not a priori exclude the possibility of referring a

44 | Decision of the CCC File No.Pl. Ús 10/17 of 3 November 2020.

45 | Decision of the CCC File No.Pl. ÚS 41/17 27 November 2018.

46 | This can be demonstrated on interpretation of the right to protection of privacy under Art. 10 of the Charter. Unlike the provisions enshrined in Art. 8 of the EU Charter, the right to protection of privacy cannot be limited 'on some other legitimate basis laid down by law'; the CCC resolved this problem by using an interpretation conforming to this provision. It did so, however, in a situation where it could have applied the EU Charter directly in terms of EU law. II. ÚS 2778/19.

47 | Decision of the CCC File No.Pl. ÚS 10/17 of 3 November 2020.

48 | Decision of the CCC File No. II. ÚS 2778/19 of 5 November 2019.

49 | Decision of the CCC File No. II.ÚS 1009/08 of 8 January 2009.

50 | Decision of the CCC File No. II. ÚS 3432/17 of 11 September 2018. 
question for a preliminary ruling, ${ }^{51}$ it does not consider itself obliged to do so, and has not done so yet in practice. ${ }^{52}$

Therefore, I cannot avoid the impression that the objective of the CCC's approach described above is to exclude any impact of EU law on its decisions. I believe that this is done deliberately as the CCC can thus escape the authority of the CJEU, without simultaneously questioning its doctrine of the effects of EU law.

However, the actual reality of the CCC's decision-making and its relationship to EU law and the CJEU is more diverse than it might appear at first sight. The Constitutional Court oscillates between two extremes. This can be demonstrated by the decision in the case of the European Arrest Warrant, where it used the linguistic approach only as a starting point and interpreted the relevant provision of the Charter of Fundamental Rights and Freedoms ${ }^{53}$ unusually narrowly. ${ }^{54}$ Further, while using other methods of interpretation with preference for an option conforming to EU law, ${ }^{55}$ it reached a conclusion opposite to what the wording of the Czech Charter might seem to indicate prima facie. This decision was very accommodating towards EU law. It fully reflects the case law of the CJEU concerning the indirect effects of EU law. The Polish Constitutional Court, for example, was not forthcoming in this regard. ${ }^{56}$

The other extreme is represented by the well-known decision in the case of 'Czechoslovak pensions' ${ }^{57}$ where the CCC-relying on the ultra vires doctrine-unambiguously and openly refused to apply EU law as previously interpreted by the CJEU. However, this case is unique. In general, a cautiously accommodating, albeit reserved, approach towards EU law and case law of the CJEU tends to prevail in the case law of the CCC. ${ }^{58}$

\section{2.3. Relationship between the CJEU and the ECtHR in case law of the CJEU}

A number of rights regulated by the Charter of Fundamental Rights of the EU and the Convention are either identical in terms of content and meaning or broad in their material scope. ${ }^{59}$ This fact, in itself, reduces the space for possible contradictions between interpretation by the CJEU and interpretation provided by the ECtHR (from the viewpoint of the CJEU).

51 | See the decision of the CCC File No. Pl. ÚS 50/04 of 8 March 2006.

52 | For a more detailed analysis see e.g. Sehnálek and Stehlík, 2019, pp. 181-199; Stehlík, 2019, pp. 150-172; Stehlík, 2019, pp. 117-129; Stehlík, 2017, pp. 577-588.

53 | Art. 14 (4) of the Charter of Fundamental Rights and Freedoms states that '[n]o citizen may be forced to leave his or her homeland'.

54 | According to Filip and Zemánek, this would not even be a case of narrow interpretation because "[e]xtradition" of a citizen and "abandonment of homeland" are two completely different categories in this regard.' Cf. Zemánek, 2006, pp. 90-95; Filip, 2005, pp. 3-7.

55 | This is a requirement following both from the Czech legal system, especially Art. 1 (2) of the Constitution, and from EU law, even with regard to the pre-Lisbon third pillar. See: Tomášek, 2006, pp. 200-203. In general, also Král, 2005, pp. 218-220.

56 | Wyrok Trybunału Konstytucyjnego z 27 kwietnia 2005 r., P 1/05 Stosowanie Europejskiego Nakazu Aresztowania Do Obywateli Polskich. Available at: http://trybunal.gov.pl/.

57 | Decision File No. Pl. ÚS 5/12 of 31 January 2012

58 | I must also emphasise that the Constitutional Court has identified certain rights within the Czech Constitution (the so called Material Core) that are non-changeable. They cannot, therefore, be changed even by EU law. The problem at the moment is only rhetorical in nature and is, therefore, hypothetical. The actual conflict has not yet occurred. For an analysis see e.g. Molek, 2014, pp.110-114. 59 | For comparison, see the commentary on Art. 52 contained in the explanations on the Charter of Fundamental Rights. 
By definition, the CJEU does not work with the ECtHR case law as often as the CCC. This is understandable, as protection of human rights and freedoms is not the primary objective of this court.

Three ways to employ the ECtHR case law and the European Convention can be inferred, in principle, from decisions of the CJEU. First, the parties often refer to these sources, and the CJEU mentions the ECtHR's arguments in the descriptive part of its judgement, but does not deal with them any further. Second, the CJEU relies on the European Convention as an argument supporting the solution chosen by the Court itself, but provides its own interpretation. ${ }^{60}$ Finally, they are reflected most clearly in cases where the CJEU refers directly to the interpretation of the European Convention as provided by the ECtHR, and works with this standard and uses it to derive its own solution to the problem. ${ }^{61}$

A relatively accommodating approach towards the ECtHR case law can be inferred from the decisions of the CJEU.62 Conflicts are, therefore, quite rare. Nevertheless, there have been cases in which a basically identical case was resolved differently by the two courts. The risk of conflict increases proportionately to the constant expansion of competences of the EU, especially into areas going beyond simple economic cooperation of the Member States. ${ }^{63}$

An example of a different approach to the same issue is offered by the case law of the two courts pertaining to advocates general and the right to a fair trial. ${ }^{64}$ This series of cases began with the ECtHR's ruling in the case of Vermeulen v Belgium, ${ }^{65}$ without any link to the EU. In that case, the role of an advocate general was similar to that of the Advocates General at the CJEU. The ECtHR ruled in a way that implied a possible issue in the regulation of activities of advocates general of the EU. Nevertheless, the CJEU deviated from the ECtHR's arguments in its own ruling in Emesa Sugar. ${ }^{66}$ In doing so, it identified elements distinguishing the position of advocates general in EU law from their analogy in Belgian law to create space for a different legal conclusion. This, undoubtedly, was the right course of action. ${ }^{67}$ The ECtHR was subsequently given the opportunity to respond to the ruling of the CJEU in the case of Kress ${ }^{68}$, where the former court dealt with an analogy (or rather

60 | See the reference to the wine-making legislation in the judgement of the Court of Justice of 13 December 1979, Liselotte Hauer v Land Rheinland-Pfalz, Case 44/79, paras. $17-19$.

61 | See, e.g., the specific quote of interpretation provided by the ECtHR in the judgement of the Court of Justice (Fourth Chamber) of 28 July 2016, JZ v ProkuraturaRejonowaEódź - Śródmieście. Case C-294/16 PPU, paras. 51 and 52.

62 | Bronckers, 2007, p. 604.

63 | Literature highlights the existence of risks especially in the area of migration and measures of criminal law. See Harpaz, 2009, p. 119.

64 | Cf. Douglas-Scott, 2006, p. 643; Lock, 2015, p. 176.

65 | Decision of the ECtHR in Vermeulen v Belgium, judgement of the Grand Chamber of 20 February 1996, application No.19075/91.

66 | Resolution of the Court of Justice of 4 February 2000, Emesa Sugar (Free Zone) NV v. Aruba, Case C-17/98.

67 | Work with facts and their impact on legal solutions is developed especially in the AngloAmerican legal environment. From this point of view, the procedure taken by the Court of Justice of the EU is a textbook example of evaluating a prior decision and its significance for a decision made in the case at hand. Cf. e.g. Slocum, 2006, p. 138 et seq.; McGregor and Adams, 2008, p. 147.

$68 \mid$ Decision of the ECtHR in Kress v France, judgement of the Grand Chamber of 7 June 2001, application No. 39594/98. 
a model) of the institution of the CJEU's Advocate General in the French legal environment. In this decision, it discussed the conclusions reached previously in the ruling of the CJEU and rejected them. ${ }^{69}$ However, no direct contradiction was noted between the arguments used by the CJEU and the European Convention, as interpreted by the ECtHR. The CJEU did not let itself be influenced by such a delicate hint made by the ECtHR and, in case C-127/02 ${ }^{70}$, it again ruled in a way incompatible with the ECtHR case law, without dealing with the ECtHR's arguments in any way ${ }^{71}$ and without any consequences in the subsequent ECtHR case law.

Therefore, it can be stated that even in this-basically exceptional-series of decisions, where the two courts had the opportunity to clarify their mutual positions, they failed to deliver. Instead, while the ECtHR firmly maintained its own approach to interpretation of the European Convention, it adopted in effect a 'defensive position' towards EU law and the CJEU.72

The CJEU cannot be expected to blindly follow the ECtHR and its case law. It has space for its own interpretation of the European Convention. If the CJEU sufficiently emphasises the difference between the facts of the case or the EU legislation in question and the case dealt with by the ECtHR or the national legislation concerned in the given case, it operates within the boundaries that each court, including courts of the Member States, has for its own discretion. In cases of such a justified deviation, the ECtHR can be expected to follow suit, rather than emphasise possible differences. This is the case in majority of the cases. I am convinced that this approach is rational and correct.

\section{| 2.4. Relationship between the CJEU and the EFTA Court in case law of the CJEU}

EU law and the EEA Agreement share a number of identical or highly similar provisions. Therefore, it is not surprising that decisions in which the CJEU was influenced by the EFTA Court in the interpretation of EU law can be found in all areas of cooperation under the EEA Agreement. ${ }^{73}$ The case law of the EFTA Court has been taken into consideration both by the CJEU and the General Court, and even by the Advocates General. ${ }^{74}$ The CJEU has accepted the authority of the EFTA Court with regard to the interpretation of EU law, and also in connection with the interpretation of the Agreement and the law adopted on its basis.

It is interesting how the CJEU works with decisions of the EFTA Court, on the one hand, and with those of the ECtHR, on the other. In the case of the ECtHR, the CJEU either refers to its decisions in very general terms or, in contrast, adopts relatively extensive arguments presented previously by this other court. The approach to the EFTA Court's decisions is different in this regard. References to these decisions are similar to those of

69 | Cf. Lock, 2015, p. 176

70 I Judgement of the CJEU (Grand Chamber) of 7 September 2004, LandelijkeVereniging tot Behoud van de Waddenzee a NederlandseVereniging tot Bescherming van Vogels v. Staatssecretaris van Landbouw, NatuurbeheerenVisserij, Case C-127/02.

71 | Unfortunately, the resolution was not published and I am thus forced to work with a quote from that decision provided in the case CooperatieveProducentenorganisatie van de NederlandseKokkelvisserij U. A. v. the Netherlands, Decision (Third Section) of 20 January 2009, application No. $13645 / 05$.

72 | See Kosař, 2006, pp. 135-141.

73 | For an overview, see e.g. Baudenbacher, 2004.

74 | Baudenbacher, 2004, p. 366. 
the earlier case law of the CJEU. It is apparent from this point of view that the CJEU perceives the EFTA Court as its equivalent counterpart. This approach resembles the work of the CCC and the way it treats the ECtHR case law.

Even this seemingly idyllic relationship between the two courts can be disrupted in individual cases by different ideas of how a certain situation should be handled. The rulings of the CJEU in Silhouette ${ }^{75}$ and of the EFTA Court in Mag Instrument Inc. v California Trading Company Norway, Ulsteen can serve as an example of such a conflict. ${ }^{76}$ Both these decisions concerned the Trade Marks Directive ${ }^{77}$ and the issue of the exhaustion of trademark rights in a situation where the goods have been placed on the market of a third country. However, the two courts resolved the case differently. While the EFTA Court accentuated the purpose of the trade mark in relation to consumer interests, ${ }^{78}$ the CJEU preferred the interest in free trade within the EU and, thus, emphasised the internal market and liberalisation within its framework.

It is worth noting that the CJEU failed to deal with the reasoning of its decision in any way with the differing ruling of the EFTA Court. It, thus, appears that the practice of the CJEU is to reflect the case law of the EFTA Court where it supports its arguments and does not mention it in cases where it does not.

\section{Conclusion}

The aim of this study was to identify rules governing the mutual relationship among the chosen supreme courts and to determine to what extent, and whether at all, these courts are mutually bound by their decisions and their interpretive conclusions. It follows from these rules that the respective positions of the individual courts in interpretation of the law differ, as do the conditions under which their decisions can affect national and EU laws. The CJEU has the power to authoritatively determine the correct interpretation of the EU Charter and the entire body of EU law. Constitutional and common courts of the Member States are then required to follow this interpretation. This does not mean that decisions of the CJEU serve as a precedent, as this body is not a law-making authority de iure, although in a number of cases it ruled de facto as if it were such an authority. According to EU law, the courts of the Member States are not bound by every decision of the CJEU, ${ }^{79}$ but have to respect the manner in which the EU Court interprets EU law (including international treaties that form part of that law).

The ECtHR does not have any similar power. This provides national constitutional courts and the CJEU with greater space for setting their own interpretation. Only a decision issued in proceedings to which the given country was a party is binding on national courts. Moreover, the ECtHR system is of a subsidiary nature and the ECtHR often works

75 I Judgement of the Court of Justice of 16 July 1998, Silhouette International Schmied GmbH 8 Co. KG v. HartlauerHandelsgesellschaftmbH, Case C-355/96.

76 | Decision of the EFTA Court of 3 December 1997, Mag Instrument Inc. v California Trading Company Norway, Ulsteen, Case E-2/97.

77 | First Council Directive 89/104/EEC of 21 December 1988 to approximate the laws of the Member States relating to trade marks.

78 | See the ruling in Mag Instrument Inc. v California Trading Company Norway, Ulsteen, para. 20.

79 | That is, even by those judicial decisions which are not addressed explicitly to them. 
with the doctrine of appreciation, which leaves room for the courts of the Member States to decide on their own interpretations and solutions. This approach is practically unknown to constitutional courts; the CJEU, too, works only rarely with such a concept, and where it does, to a very limited extent.

The EFTA COURT is restricted in terms of the interpretation of the EEA Agreement. The Agreement explicitly specifies what is merely inferred by a part of the doctrine in the case of the CCC and its relationship to the ECtHR: the European Convention is binding on the Czech Republic and the Czech courts as interpreted by the ECtHR. However, even the justices of the CCC are not unanimous as to whether this is true. While some emphasise the precedential nature of the ECtHR decisions, ${ }^{80}$ others accentuate the subsidiary nature of the whole system of the European Convention.

Another goal was to present the reality of judicial decision-making. The judgements reviewed indicate some systemic differences: they are admitted only to a limited degree (CCC) or not at all (CJEU), but they do exist. There is a clear difference in how the CCC approaches decisions of the ECtHR and the CJEU. Similarly, it can be seen that the CJEU works differently with decisions of the ECtHR and the EFTA Court. The CCC and CJEU also have in common that they treat decisions of the ECtHR (CCC) and the EFTA Court (CJEU) as their own. The influence of these courts on the interpretation of law is substantial.

It is also apparent that the general attitude of all the courts involved is open to cooperation and dialogue. The courts tend to avoid conflicts in their decision-making. While disputes occasionally occur, they are usually insignificant. A high degree of imitation and copying of the conclusions is apparent.

Finally, the objective was to determine whether a final interpretation authority can be established unambiguously de iure or at least de facto in our European space. I believe that none of the courts under scrutiny have such a position. The CJEU comes closest to this mark when interpreting EU law. This court strives actively to prevent any possible threats to this position, which is the reason why the EU has yet to accede to the European Convention. Realistically, however, it cannot prevent the ECtHR or national constitutional courts from making decisions that contradict what it has established. This has already occurred more than once.

80 | The same applies to decisions of the Court of Justice and, within national law, to rulings made by the CCC. Such an approach is often justified by arguments based on the stability of case law, the principle of legal certainty, the principle of predictability of judicial decision-making, hierarchical subordination and the possibility that if a different decision is made than previously by a higher court, the case will eventually arrive at the same court and the court will decide it in the same way (because it so wishes or because it must do so based on the rules of its functioning), etc. In respect of decisions of the Court of Justice, see e.g. Kaczorowska-Ireland, 2016. 


\section{Bibliography}

Kuijer, M. (2011) 'The Accession of the European Union to the ECHR: A Gift for the ECHR's 60th Anniversary or an Unwelcome Intruder at the Party?', Amsterdam Law Forum, 3(4), pp. 17-32. Available at: http://amsterdamlawforum.org/.

Baudenbacher, C. (2004) 'The EFTA Court: An Actor in the European Judicial Dialogue', Fordham International Law Journal, 28(2), pp. 353-391.

Bronckers, M. (2007) 'The Relationship of the EC Courts with Other International Tribunals: Non-committal, Respectful or Submissive?', Common Market Law Review, 44(3), pp. 601-627.

Douglas-Scott, S. (2006) 'A Tale of Two Courts: Luxembourg, Strasbourg and the Growing European Human Rights Acquis', Common Market Law Review, 43(3), pp. 629-665.

Filip, J. (2005) 'Evropský zatýkací rozkaz a rozhodování ústavních soudů [European Arrest Warrant and Judicial Practice of Constitutional Courts.]', Právní zpravodaj, 6(8), pp. 3-7.

Forejtová, M. (2015) Přistoupit či nepřistoupit k EÚLP - to je oč tu už neběží. [To Accede or Not to Accede to the ECHR - That is No Longer the Question.] [Online]. Available at: http://www.pravniprostor.cz/.

Hamulák, O. (2016) National Sovereignty in the European Union: View from the Czech Perspective. Cham: Springer International Publishing AG..

Hlinková, K. (2016) 'Interakce Soudního dvora EU a Soudního dvora Evropského sdružení volného obchodu. [Interactions of the EU Court of Justice and the Court of the European Free Trade Association.]' in Sehnálek, D., Týč, V. (eds.) Soudní dvůr EU a výklad práva Evropské unie. [Court of Justice of the EU and Interpretation of European Union Law.] Brno: Masaryk University, pp. 950-111.

| Kaczorowska-Ireland, A. (2016) European Union Law. 4th Edition. London: Routledge. Kosař, D. (2006) 'Co si myslí štrasburský soud o lucemburských institucích? [What is the Stance of the Strasbourg Court on Luxembourg Institutions?]', Právní rozhledy, 2006/4, pp. 135-141.

Král, R. (2005) 'K přezkumu ústavnosti českých předpisů transponujících, popř. implementujících komunitární či unijní akty. [On the Review of Constitutionality of Czech Laws Transposing or Implementing Community or Union Acts.]', Právní rozhledy, 2005/ 6, pp. 218-220.

Lock, T. (2015) The European Court of Justice and International Courts. Oxford University Press.

Molek, P. (2014) Materiální ohnisko ústavy: věčný limit evropské integrace? Brno: Masarykova univerzita. 
Mcgregor, D. B., Adams, C. M. (2008) The International Lawyers Guide to Legal Analysis and Communication in the United States. New York: Aspen Publisher.

Sehnálek, D., Stehlík. V. (2019) "European "Judicial Monologue" of the Czech Constitutional Court: A Critical Review of its approach to the Preliminary Ruling Procedure', International and Comparative Law Review, Univerzita Palackého V Olomouci, 19 (2), pp. 181-199.

Stehlík, V., Sehnále, D. (2019) 'The Use of the Preliminary Ruling Procedure by Czech Courts: Historical Retrospective and Beyond', Baltic Journal of European Studies. Tallinn University of Technology, 9(4), pp. 150-172.

Stehlík, V. (2019) 'Constitutional review and the preliminary ruling procedure: Commentary on the CCB decision of the Czech Constitutional Court', Czech Yearbook of International Law, 2019/10, pp. 117-129

Stehlík, V. (2017) 'Application of CILFIT Criteria by Czech Supreme Courts', Czech Yearbook of International Law, 2017/8, pp. 577-588.

Tomášek, M. (2006) 'Cesty k eurokonformnímu výkladu v trestním právu. [Paths towards Euro-conforming Interpretation in Criminal Law.]', Trestněprávní revue, 2006/7, pp. 200-203.

Týč, V. (2017) Základy práva Evropské unie pro ekonomy. [Basics of EU Law for Economists.] 7th edition. Prague: Leges, s.r.o..

Zemánek, J. (2006) 'Evropskoprávní meze přezkumu ústavnosti transpozice rámcového rozhodnutí o eurozatykači. [European-law Limits to Review of Constitutionality of the Transposition of the Framework Decision on European Arrest Warrant.]', Právní rozhledy, 2006/3, pp. 90-95. 